\title{
Understanding Defense Cooperation Between Indonesia-China Through State Owned Enterprise (Norinco and Indonesia's Government)
}

\author{
Arinaldo Habib Pratama, S.IP, M.Han \\ Universitas Budi Luhur ${ }^{l}$
}

\begin{abstract}
ABSTRAK
Saat ini, Indonesia dan China menjalankan berbagai kerjasama di berbagai bidang, termasuk pertahanan. Kerjasama Indonesia-China merupakan strategi penjagaan bagi Indonesia. Kedua, Indonesia menganggap Kerjasama Pertahanan Indonesia-China memiliki nilai strategis. Hasil penelitian menunjukkan, bahwa kekuatan Alat Utama Sistem Senjata (Alutsista) TNI saat ini memang dalam kondisi yang lemah, atau belum memenuhi standar kekuatan pokok minimum (minimum essential force), sehingga Indonesia perlu melakukan usaha peningkatan kekuatan Alutsista TNI melalui Kerjasama Pertahanan Indonesia-China. Sedangkan nilai strategis yang dimaksud adalah bahwa Kerjasama Pertahanan IndonesiaChina, bagi Indonesia menguntungkan dari segi alih teknologi, ekonomi, dan politik. Menguntungkan dari segi alih teknologi karena dalam kerjasama ini China bersedia melakukan alih teknologi. Dari segi ekonomi menguntungkan karena harga peralatan militer China murah. Dan segi politik menguntungkan karena China tidak menyertakan syaratsyarat politik dalam kerjasama ini. Selain itu kerjasama pertahanan ini juga dapat menyeimbangkan hubungan dengan negara-negara besar, khususnya dengan Amerika Serikat.
\end{abstract}

Kata Kunci : Indonesia, China, Kerjasama Pertahanan, NORINCO, Persenjataan

\section{PENDAHULUAN}

China and Indonesia currently carrying bilateral cooperation in various sector, especially in defense sector. This is different from the past, when Indonesia under leadership of President Soeharto decided to cut off bilateral relationship with China in 1950, caused by China's involvement in 30 September 1965 rebellion, which conducted by Communist Party of Indonesia (Partai Komunis Indonesia). It tooks 35 years before the relationship resumed, through the signing of Memorandum of Understanding (MoU) between Indonesia's Foreign Minister Ali Alatas and China's Foreign Minister. In 1985, the two countries initiated contact to discuss the

\footnotetext{
${ }^{1}$ Arinaldo Habib Pratama adalah asisten dosen di Jurusan Hubungan Internasional, Universitas Budi Luhur. Menyelesaikan pendidikan S1-nya di Jurusan Hubungan Internasional Universitas Andalas pada tahun 2015 dan pendidikan S2 di Prodi Manajemen Pertahanan, Universitas Pertahanan pada tahun 2018.
} 
resumption of diplomatic relations. As the result, Chinese President Yang Shankun and Chairman of National People's Congress Qiao Shi visited Indonesia in 1991 and 1993. Several high ranking Indonesian officials, including President Soeharto visited China. Beginning in 1991, the two countries's foreign ministeres set up a consultation mechanism ${ }^{2}$.

China and Indonesia shared common interests. In economic term, As far as Indonesia was concerned, policy-makers in Jakarta saw China's economic opening, particularly following its accession to the World Trade Organization in 2001, and its intention to engage ASEAN as a whole as both an economic opportunity and a threat. It was an opportunity because China's 1.2 billion people were a huge potential market for Indonesian exporters to exploit ${ }^{3}$. In development term, cooperation with China also involved in building of various infrastructure through government to government ( $G$ to $G$ ) scheme or business to government (B to $G$ ) scheme. The surge in Chinese investment into infrastructure started with A US\$ 20bn Memorandum of Understanding with the China Development Bank (CDB), signed in June 2015, to finance infrastructure, which is planned to be channeled through SOEs; CDB is also expected to provide finance for the planned Jakarta-Bandung High Speed Rail Line ${ }^{4}$

Defense also become aspect that connect those two countries together. Indonesia anc Chinese need each other in this matter. Indonesia need secure their maritime interest which already described in Wawasan Nusantara, while China also need to secure strategic sea lane in various place that could be described as their maritime border, like South China Sea. From this interest, the cooperation could be stretched from military modernisation to capacity building. Apart from its multilateral engagements, the Indonesian government also undertakes a steady process of military modernisation to maintain the country's "standard deterrence" ability. Under the socalled "minimum essential force" (MEF) strategy, it has outlined the nature and scale of capabilities to anticipate a broad array of military operations at the perceived flashpoints. Moreover, in order to gain a higher level of self-reliance on arms manufacturing, Jakarta seeks to revamp the capabilities of its strategic industries base through defence industrial partnership ${ }^{5}$.

\footnotetext{
${ }^{2}$ Wei Liu, China in the United Nations, 2014, World Scientific, hal.166

${ }^{3}$ Alexander Chandra, Indonesia-China Trade Relations : The Deepening of Economic Integration and Uncertainty, 2011, International Institute of International Development, hal.8

${ }^{4}$ Price, Water and Cooper, Indonesia Infrastructure : A Foundation of Growth, hal.35. Also read http://www.thejakartapost.com/news/2015/06/18/statefirms- get-20b-loan-commitment-chinabank.html.

${ }^{5}$ Iis Gindarsah, Indonesia Defence Diplomacy : Harnessing The Hedging Strategy Against Regional Uncertainties, 2015, Rajaratman School of International Studies Working Paper, Singapore, hal. 16
} 


\section{Tinjauan Pustaka}

\section{Defense Cooperation ${ }^{6}$}

United States's Department of Defense (DOD) define defense cooperation as :

All DoD interactions with foreign defense establishments to build defense relationships that promote specific U.S. security interests, develop allied and friendly military capabilities for self-defense and multinational operations, and provide U.S. forces with peacetime and contingency access to a host nation.

To conduct a succesful defense cooperation, there has to be requirement that has to be fulfilled. Clingendael or Netherland Institute of International Relations explain those requirement with those points :

- Trust, confidence and solidarity: generally, this is regarded as the most important success factor, in particular for operational defence cooperation. The more partners trust each other, the easier cooperation will be - though not automatic.

- Sovereignty and autonomy: maintaining national sovereignty is often mentioned as a crucial blocking factor for deeper defence cooperation.

- Geography and history: most forms of deeper operational defence cooperation exist between neighbouring countries.

- Number of partners: the general rule is that multinational defence cooperation will be more difficult when the number of participants goes up.

- Countries and forces of similar size and quality: cooperation between countries of different size can be hindered by fear of domination (by the smaller) or by ignoring the needs of the other (by the bigger partner).

- Top-down and bottom-up: strong leadership at the political and the top military level is essential for defence cooperation to succeed, but equally bottom-up full engagement of military experts is required.

- Defence planning alignment: especially permanent forms of defence cooperation will require partners to align their defence planning.

${ }^{6}$ Margriet Drent, Defence Cooperation in Clusters : Identifying the Next Steps, 2014, Clingendael, hal. 


\section{Balance of Power $^{7}$}

The aspiration for power on the part of several nations. each trying either to maintain or overthrow the status quo. leads of necessity to a configuration that is called the balance of power and to policies that aim at preserving it.

According to Morgenthau, balance of power refers to an actual state of affairs in which power is distributed among several nations with approximate equality. When any state becomes or threatens to become, inordinately powerful, other states should recognise this as a threat to their security and respond by taking equivalent measures, individually, and jointly to enhance their power.

\section{Defence Strategy}

National defence always follows this strategic principle :

- State's capacity and will to act. In a situation when threats are changing and difficult to predict, the ability of the state power to anticipate potential threats and to respond thereto must be developed.

- Deterrence policy as a mean for minimising external military threats. It is the objective of national defence to deter an adversary from their intention to use military force.

- Implementation of national defence and overcoming of external threats. National defence will be implemented as a form of collective defence

\section{SWOT}

Fredi Rangkuti (2004: 18) explaining SWOT analysis as identification of various factor to formulise company strategy. The analysis would be based on conclusion to maximise strength $(\mathrm{S})$ and opportunity $(\mathrm{O})$, while minimise impact of weakness $(\mathrm{W})$ and threat $(\mathrm{T})$.

\section{Pembahasan}

\section{China's SWOT Formulation}

\section{Strength}

Economically, China through open economy policy or what they usually called as Kaifeng Zhenze enable them to be the current most greatest economy in the world, of

\footnotetext{
${ }^{7}$ Morgenthau, Hans J, and Kenneth W. Thompson. Politics Among Nations: The Struggle for Power and Peace.
} 
course together with their huge number of population or demography (currently stands in 1.38 billions people ${ }^{8}$ ).

China's government use this opportunity to built manufacture-based economy, which started by Deng Xiaoping regime, through importation of foreign made tools and machine and encouraging joint venture between China's origin company and foreign company ${ }^{9}$.

As the result, China able to overtake United States as one of greatest manufacturing power in the world. At 2014, the value of China's manufacturing on a gross value added basis was $39.6 \%$ higher than the U.S. level. Manufacturing plays a considerably more important role in the Chinese economy than it does for the United States. In 2014, China's gross valued added manufacturing was equal to $27.7 \%$ of its GDP, compared to $12.1 \%$ for the United States ${ }^{10}$.

China currently has biggest Gross Domestic Product (GDP) in the world. Currently, this country produce GDP as many as USD 25.1 trillion. Meanwhile, her closest competitor, which is United States, only able to reach USD 21.7 trillion at the same time. Today, Beijing, the capital of China, has the biggest number of richest people in the world live in the city. According to Forbes report, Beijing has 65 members of Forbes China Rich List, which has total members as many as 400 names $^{11}$.

To ensuring economic activity in China will running smoothly, connectivity is the key to ensure this happen. Mainland China, which has broad region, need a well prepared infrastructured so the development would be distributed equally into entire parts of country. Currently, China has toll road with distance of $95.000 \mathrm{~km}$, fast train with total distance $20.000 \mathrm{~km}$, airport as many as 224 unit, port as many as 2.000 unit, and cargo ship as many as 5.000 unit.

The combination of competitive entrepreneur, numbers of large companies, and advanced manufacture, result in growth in trade between China's and her partner countries. Annually, the number of China's trade is USD 2.27 trillion in export and USD 1.79 trillion in import. The country itself keep having surplus in trade, even they oftenly organise import expo to show the world that the economy keep flourishing, so China's will be able to fulfill their intention to buy best commodity from around the world. One example is Shanghai Expo. In Shanghai Expo, Enterprises from over 100

\footnotetext{
${ }^{8}$ Population of China, https://www.statista.com/topics/1276/population-in-china/

${ }^{9}$ Rusdi Omar, China dan Kuasa Hegemoni Baru Ekonomi, International Journal of Management Studies, Universiti Utara Malaysia, hal. 11

${ }^{10}$ Wayne M. Morrison, China's Economic Rise : History, Trends, Challenges and Implications for the United States, 2018, Congressional Research Service, Washington DC

${ }^{11}$ Beijing Is China's Capital of Billionares, too, https://www.forbes.com/sites/russellflannery/2017/11/30/beijing-is-chinas-capital-of-billionairestoo/\#74f18c721d4b, November 30, 2017
} 
countries and regions are participating. Supporting activities such as supply-demand matchmaking meetings, seminars and product releases will be held during the Expo ${ }^{12}$.

In terms of military, China has third largest military in the world, with active personnel as many as 2.2 million personnel. In 2017, China succedding in building first aboard base.

\section{Weakness}

The surpluses of China's economy could created what we could called as bottleneck problem. In bottleneck problem, China's create more stuff more than how many domestic and international market need. Its preference for manufacturing dominance over the fostering of a balanced economy means that China will perpetually produce more stuff than it can use. It will generate great manufacturing surpluses that, however impressive they look, will only do China good if its state-owned firms can sell them. Without buyers, stacks concrete reinforcement bars and jet engines only rust in factory yards. This phenomena would halt China effort to acquire foreign currency to anchor their own currency, especially in event of global economy stagnation $^{13}$.

The example of China's production surpluses could be seen in steel. According to a recent report by BMI Research, China will produce 825 million metric tons of crude steel next year, a 0.5 percentage point increase from 2016-yet will consume 87 percent of this production. This is because continuing Chinese fiscal support to the construction sector, yet the export of China's steel might be fall because unsuitable with international environmental standard. The push to decrease development due to pollution that could be created, will create less China's export ${ }^{14}$.

\section{Threat}

Although China's is one of few countries that has billion population, but currently aging population become of significant problem of this country. With one-child policy (including sanction to anyone that intentionally has more than one children and permission to parent that has twins) the growth of population keep falling, from 2.8 children per women in 1979 to 1.7 children in 2014. Also, the growth of economies would motivate people to saving more than spending, thus created low motivation to have second children. According to survey that conducted by Chinese website,

\footnotetext{
12 About Us, https://www.shanghaiexpo.org.cn/zbh/Introduction/

${ }^{13}$ Forbes, In This Game Of Threats, China Carries Fundamental Weaknesses, https://www.forbes.com/sites/miltonezrati/2018/04/09/in-this-game-of-threats-china-carriesfundamental-weaknesses/\#3bd333ae4660

${ }^{14} \mathrm{CNBC}$, China will produce more steel in 2017, but they'll also use most of it themselves, https://www.cnbc.com/2016/12/30/china-will-produce-more-steel-in-2017-but-theyll-also-use-most-ofit-themselves.html , 20 November 2017.
} 
Sina.com, only 1 in 3 couples indicated that they would have a second child as a result of loosening of one child policy ${ }^{15}$.

\section{Opportunities}

The opportunities that China has in order to reach their national interest is cooperation between China and her partner countries. China has veto power in United Nation's Security Council. China also become active member in more than 70 international organisation, and also involving in 500 multilateral treaty and 24.000 bilateral treaty.

\begin{tabular}{|l|l|}
\hline Strength & Weakness \\
\hline - Open economy & - Bottleneck problem \\
- GDP & \\
$-\quad$ Industrial-based economy & \\
$-\quad$ Powerful economy & \\
- Military & Opportunities \\
\hline Threat & - International cooperation \\
\hline - Aging society & \\
\hline
\end{tabular}

Table 1 : Strength, Weakness, Opportunities and Threat of China

\section{Balance of Power through Indonesia-China Military Cooperation}

After the explanation of BRI cooperation in economic scope, now Mr Xi continue his presentation into defense cooperation between Indonesia and China. Mr. Xi started his explanation with stated that China as a country has active defense doctrine in order to protect their sovereignty. Active defense, in historical context, is inseparable from China's defense idea, since it come from Mao Zedong thought :

"...defensive warfare, which is passive in form, can be active in content, and can be switched from the stage in which it is passive in form to the stage in which it is active both in form and in content. In appearance a fully planned strategic retreat is made under compulsion, but in reality it is effected in order to conserve our strength and bide our time in order to defeat the enemy, to lure him in deep and prepare for our counter offensive. ${ }^{16}$ ",

\footnotetext{
${ }^{15}$ China Power, Does China have an aging problem ?, Centre of Strategic and International Studies, https://chinapower.csis.org/aging-problem/

${ }_{16}$ Zedong, Mao. "Strategy in China's Revolutionary War." Ed. Gérard Chaliand. The Art of War in World History: From Antiquity to the Nuclear Age. Berkeley: University of California, 1994. 976-88. Print.
} 
This could be interpreted as while China still pursuing military modernisation and self reliance as quickly as possible, China able to mitigate conflict through bilateral and multilateral cooperation. For example, the visit from India's Prime Minister, Narendra Modi to Wuhan in order to meeting Xi Jinping in May 2018, in the middle of border dispute that happened in Doklam Plateau, is a form of interpretation that could be seen as China's effort to boost common prosperity and engagement rather than confrontation and escalation ${ }^{17}$.

The capacity of China to hold themselves to not involved themselves into confrontation would enable Indonesia to launch military cooperation. Mr Xi suggest that China has interest to conduct defence cooperation in form of transfer of technology, joint venture and joint training.

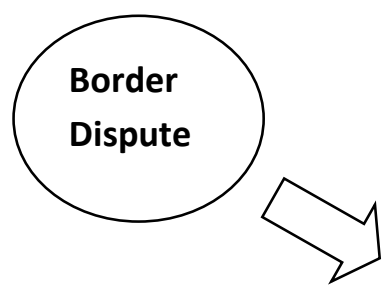

Pull Factor

Determinant
Factor of
Indonesia-
China Defense
Cooperation
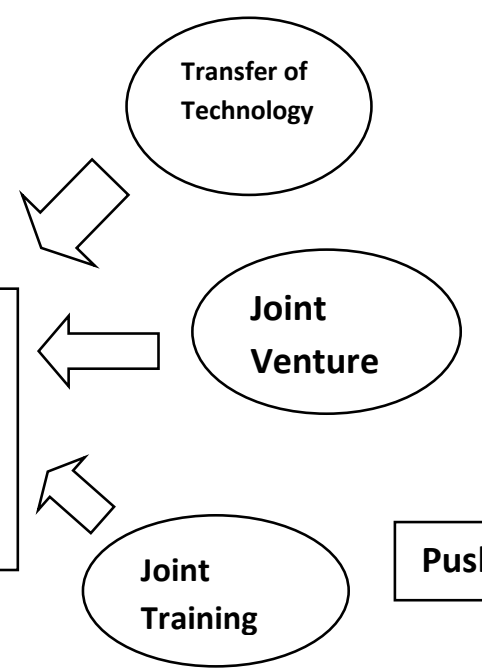

Push Factor

\section{Image 1: Pull Factor (Constraint) and Push Factor (Insentive) from Indonesia- China Defence Cooperation}

The example of transfer of technology that already done by Indonesia and China is development of C-705 by Indonesia and China defence industry. C-705 missile is middle range missile which has average range of $75 \mathrm{~km}$ if the missile doesn't use the booster, and $170 \mathrm{~km}$ if the missile use the booster. The weight of warhead is reach $110 \mathrm{~kg}$, categorised as HVDT-H high explosive. This missile could destroy ship that

\footnotetext{
17 The Diplomat, Beyond Wuhan: India Should Establish A New Framework for Engagement With China, https://thediplomat.com/2018/05/beyond-wuhan-india-should-establish-a-new-framework-forengagement-with-china/, 1 May 2018.
} 
has weight as same as 1.500 ton, at maximal. The announcement of cooperation is conducted at 23 May 2014.

The transfer of techology from China's miitary to Indonesia defence industry took 2 steps. First, Semi Knock Down (SKD) that would be conducted by PT Dirgantara Indonesia with time range from 2-3 years. Semi Knock Down is guided missile's assembling that conducted by PT Dirgantara Indonesia, which most of the missile material still imported from initial producer. Second, Completed Knock Down, is the importation of missile component from Tiongkok also including the guide technology, in order to polish airframe and missile propelant that produced by PT Dirgantara Indonesia. If both of step is finished, PT DI is ready to produce domestically made C705.

The cooperation that built between Indonesia and China in manufacturing C705 missile has positive impact on Indonesia's miitary capability. The positive impact including the acquisition of sensor and guide technology that would enable C705 to search the target automatically. Also, Indonesia already kapable to create their own fast missile boat, so the ship has to be armed.

\section{How NORINCO Activities Are Compatible With China's Government Policy}

From the economic and social effectiveness point of view, national defense development has a 'spillover' effect to economic development. The positive 'spill out' effects of national defense expenditure on economic development, which are promoting scientific and technological innovation and an investment of $\$ 1$ in defense technology can bring $\$ 8$ to GDP when technology in adopted in the civilian field, according to statistics from relevan US institutions.

Private enterprises are encouraged to participate in military industrial. mid-1990s, and it entailed a crucial shift in policy, from conversion (i.e., switching military factories over to civilian use) to the promotion of integrated dual-use industrial systems capable of developing and manufacturing both defense and military goods. This new strategy was embodied and made a priority in the defense industry's five-year plan for 20012005, which emphasized the dual importance of both the transfer of military technologies to commercial use and the transfer of commercial technologies to military use, and which therefore called for the Chinese arms industry to not only to develop dual-use technologies but to actively promote joint civil-military technology cooperation. Those are action taken by China's government to support civil military integration : 
1. National defense and economic development were two majors tasks (19491977)

When New China was founded in 1949, national economy and the society were to be revived. In this background, the government believed that China must build strong national defense and strong economy. Neither of these two major tasks is dipensable. At that time, state leaders also realized that build strong national defense, the primary mission was to boom economy.

2. National defense was subordinate to and served economic development (19781997)

Since 1978, China had begun to reform and open up. The whole nation shifted focus onto economic development. National defense development was subordinate to and served economic development. Den Xiaoping said that the military have to wait and be patient.

In this period the living conditions of military people were very difficult for them to find wives or husbands, to have houses and families, and to find jobs when they quit the army. This also affected their enthusiasm to devote themselves to national defense.

3. National defense was compatible with economic development (1998-2012)

From the mid-1990s, Chinese government had gradually increased input in national defense. The input rose along with economic rapid development. This growth of input was only a "compensatory" or "restorative".

4. Promoting civil and military integration development (2012-now)

Now, China's economy is developing very well and made some achievements. Based on the economic growth, the government has increased investment in national defense and estabalished the civil and military integration development ${ }^{18}$

\section{Defense Cooperation between NORINCO and Indonesia's Defence Industry}

The cooperation of NORINCO and Indonesia's defense industry is needed because as one of China's industry, NORINCO able to export their armament product to the entire world and signifying their title to be world class industry. From the information that researcher able to get during the visitation to NORINCO expo room, which it located in A12 Guanganmen Nan Jie, Beijing, China, researcher understand that

\footnotetext{
${ }^{18}$ Crane, Keith, Modernizing China's Military : Opportunities and Constraints, RAND Project Air Forces, pg.24-26.
} 
NORINCO already visit Indonesia many times to promote their armament product, such as through expo. For example, at Indo Defence 2016, NORINCO promote their product, which identified as VN18 AAV, which is a amphibious assault vehicle, and Sky Dragon 50, an anti air missile shield system ${ }^{19}$.

There's a hope that Indonesia defence industry will follow the same step, especially because the cooperation already happen from a long time ago. The cooperation start from 2005, when Indonesia's state minister for research and technology, Kusmayanto Kadiman, announce that two countries will sign an agreement on the development of short, medium, and long range missile during President Yudhoyono's to China. In July 2005, China and Indonesia signed a bilateral MoU on defense technology cooperation. China agreed to provide technical assistance to Indonesia's aircraft and ship-building defense industries and engage in co-production of ammunition, arms and locally produced missile with a range up to 150 kilometers $^{20}$.

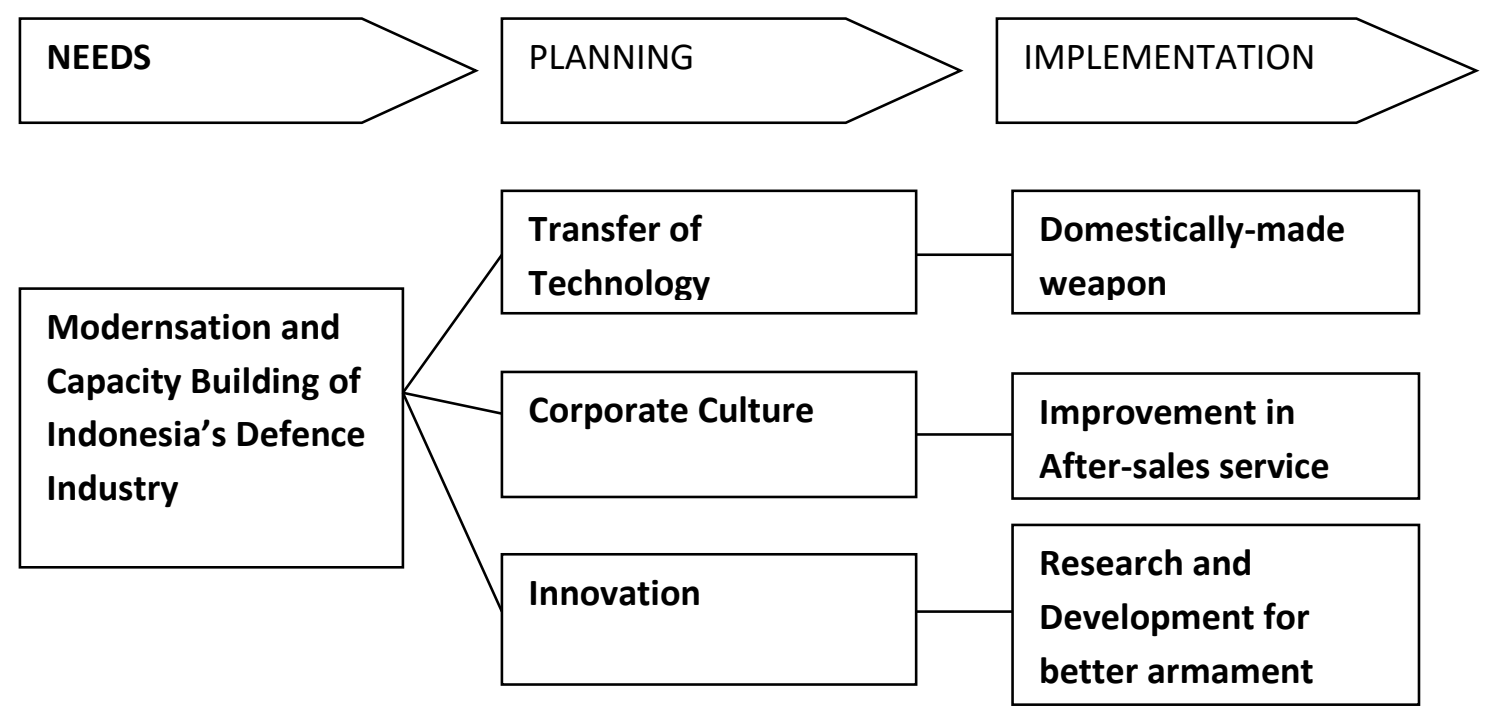

\section{Image 2 : Flow chart of Defence Cooperation NORINCO and Indonesia Defence Industries}

As a a company, NORINCO always conduct communication between their partner, both for transfer of technology (TOT) and updating the current situation of armament that bought by another countries. In cooperation with Indonesia's defence industry context, TOT is process of moving knowledge, knowhow, or method from a

\footnotetext{
${ }^{19}$ Monch Publishing Group, Indo Defence 2016: Norinco Shows New VN18 AAV, http://www.monch.com/mpg/news/land/219-indo-defence-2016-norinco-shows-new-vn18-aav.html

${ }^{20}$ James Clad, The Borderlands of Southeast Asia : Geopolitics, Terrorism and Globalization,2011, National Defense University Press, hal.45-47.
} 
government, university, or an institution so the knowledge would be able to used by many people and also to be used commercially.

There are many reason for China through NORINCO to allow TOT happened, start from to test the effectivity of their own weapon if used by another countries as user, to ensure the access of comodity that owned by partner countries, and to ensure the security of trade route. Both NORINCO and Indonesia's defence industry can't conduct the cooperation from each side, since both of entities are state company, so they need the legitimation from related ministry or military. For example, the reason of the cooperation between NORINCO and PT DI in assembly of C705 could be happen because Indonesia, through Ministry of Defence and Ministry of Technology and Research, have mutual interest with China's military and ministry that supervise NORINCO. At first time when the cooperation conducted, Indonesia's intend to made their own missile, while China concern to boost capability of NORINCO in global market.

Another reason why Indonesia's defence industry should cooperate with NORINCO is NORINCO has corporate culture that ensure the buyer will get best quality product. From the finding that researcher could get in NORINCO, What China's military standard has, the same also should be applied to the weapon that bought by the foreign buyer. For example, in commercial discussion, the buyercould discard the component that you thought would not be necessary. But NORINCO can't accept that action when it comes to military application. That's why, NORINCO always do the test in various terrain so we could detect how much percentage the weapon already prepared, it could be $25 \%, 50 \%$, or even $100 \%$.

NORINCO also leading in innnovation. Norinco has diferrent research department for different weapon to make new model, every year we have new program to create new product also we keep up by sharing information with different user. To evaluate the products that NORINCO sold, NORINCO have some cooperation with partner states to sharing information, regarding to how each countries weapon system operated, so evaluation could be conducted.

\section{Conclusion}

Current situation of TNI's main armamment is inadequate or haven't fulfilled the minimal requirements of minimum essential force (MEF), so Indonesia have to take efforts to improve the capacity of TNI through Indonesia-China defence cooperation. This cooperation is beneficial to Indonesia because China willing to do transfer of technology and the price that enabled by the China's counterpart is reasonable and affordable. 


\section{DAFTAR PUSTAKA}

Alexander Chandra, Indonesia-China Trade Relations : The Deepening of Economic Integration and Uncertainty, 2011, International Institute of International Development

Iis Gindarsah, Indonesia Defence Diplomacy : Harnessing The Hedging Strategy Against Regional Uncertainties, 2015, Rajaratman School of International Studies Working Paper

Keith Crane, Modernizing China's Military : Opportunities and Constraints, RAND Project Air Forces.

Mao Zedong. "Strategy in China's Revolutionary War." Ed. Gérard Chaliand. The Art of War in World History: From Antiquity to the Nuclear Age. Berkeley: University of California, 1994. 976-88. Print.

James Clad, The Borderlands of Southeast Asia : Geopolitics, Terrorism and Globalization,2011, National Defense University Press

Richard A. Bitzinger, Civil Military Integration and Chinese's Military Modernization, Asia--Pacific Centter ffor Securiitty Sttudiies Vollume 3 -- Number 9, December 2004

Wei Liu, China in the United Nations, 2014, World Scientific

Price, Water and Cooper, Indonesia Infrastructure : A Foundation of Growth, PWC Publishing, Jakarta

Rusdi Omar, China dan Kuasa Hegemoni Baru Ekonomi, International Journal of Management Studies, Universiti Utara Malaysia

Wayne M. Morrison, China's Economic Rise : History, Trends, Challenges and Implications for the United States, 2018, Congressional Research Service, Washington DC

\section{WEBSITE}

CNBC, China will produce more steel in 2017, but they'll also use most of it themselves, $\quad$ https://www.cnbc.com/2016/12/30/china-will-produce-more-steel-in2017-but-theyll-also-use-most-of-it-themselves.html , 20 November 2017.

China Power, Does China have an aging problem ?, Centre of Strategic and International Studies, https://chinapower.csis.org/aging-problem/ 
Forbes, Beijing Is China's Capital of Billionares,too, https://www.forbes.com/sites/russellflannery/2017/11/30/beijing-is-chinas-capital-ofbillionaires-too/\#74f18c721d4b , November 30, 2017

Forbes, In This Game Of Threats, China Carries Fundamental Weaknesses, https://www.forbes.com/sites/miltonezrati/2018/04/09/in-this-game-of-threats-chinacarries-fundamental-weaknesses/\#3bd333ae4660

Monch Publishing Group, INDO DEFENCE 2016: NORINCO SHOWS NEW VN18 $A A V, \quad$ HTTP://WWW.MONCH.COM/MPG/NEWS/LAND/219-INDO-DEFENCE2016-NORINCO-SHOWS-NEW-VN18-AAV.HTML

The Diplomat, Beyond Wuhan: India Should Establish A New Framework for Engagement With China, https://thediplomat.com/2018/05/beyond-wuhan-indiashould-establish-a-new-framework-for-engagement-with-china/, 1 May 2018 